\title{
Future climate and adverse health effects caused by fine particulate matter air pollution: case study for Poland
}

\author{
Marko Tainio - Katarzyna Juda-Rezler • \\ Magdalena Reizer · Aleksander Warchałowski • \\ Wojciech Trapp · Krzysztof Skotak
}

Received: 17 May 2012/Accepted: 19 October 2012/Published online: 15 November 2012

(C) The Author(s) 2012. This article is published with open access at Springerlink.com

\begin{abstract}
Ground level air pollution, especially fine particulate matter $\left(\mathrm{PM}_{2.5}\right)$, has been associated with a number of adverse health effects. The dispersion of $\mathrm{PM}_{2.5}$ through the atmosphere depends on several mutually connected anthropogenic, geophysical and meteorological parameters, all of which are affected by climate change. This study examines how projected climate change would affect population exposure to $\mathrm{PM}_{2.5}$ air pollution in Poland. Population exposure to $\mathrm{PM}_{2.5}$ in Poland was estimated for three decades: the 1990s, 2040s and 2090s. Future climate conditions were projected by Regional Climate Model RegCM (Beta), forced by the general atmospheric circulation model ECHAM5. The dispersion of $\mathrm{PM}_{2.5}$ was simulated with chemical transport model CAMx version 4.40. Population exposure estimates of $\mathrm{PM}_{2.5}$ were 18.3,
\end{abstract}

\section{Tainio $(\bowtie)$}

Systems Research Institute (SRI), Polish Academy of Sciences,

Ul. Newelska 6, 01-447 Warsaw, Poland

e-mail: marko.tainio@ibspan.waw.pl

M. Tainio

National Institute for Health and Welfare (THL),

P.O. Box 95, 70701 Kuopio, Finland

K. Juda-Rezler · M. Reizer

Warsaw University of Technology, Nowowiejska 20,

00-653 Warsaw, Poland

A. Warchałowski · W. Trapp

EKOMETRIA Sp. z o.o., Orfeusza 2, 80-299 Gdańsk, Poland

K. Skotak

National Institute of Public Health-National Institute of Hygiene (NIZP-PZH), Chocimska 24, 00-791 Warsaw, Poland

K. Skotak

Institute of Environmental Protection, National Research

Institute, Krucza 5/11d, 00-548 Warsaw, Poland
17.2 and $17.1 \mu \mathrm{g} / \mathrm{m}^{3}$ for the $1990 \mathrm{~s}, 2040 \mathrm{~s}$ and $2090 \mathrm{~s}$, respectively. $\mathrm{PM}_{2.5}$ air pollution was estimated to cause approximately 39,800 premature deaths in the population of Poland in the year 2000. Our results indicate that in Poland, climate change may reduce the levels of exposure to anthropogenic particulate air pollution in future decades and that this reduction will reduce adverse health effects caused by the air pollution.

Keywords Air pollution - Particulate matter Climate change $\cdot$ Health $\cdot$ Exposure $\cdot$ Poland

\section{Introduction}

Fine particulate matter $\left(\mathrm{PM}_{2.5}\right.$, particulate matter with an aerodynamic diameter of less than $2.5 \mu \mathrm{m}$ ) causes adverse health effects worldwide. The previous health impact assessment studies have estimated that $\mathrm{PM}_{2.5}$ causes over 800,000 premature deaths annually, worldwide (Cohen et al. 2005), and around 350,000 premature deaths in Europe alone (Watkiss et al. 2005). The World Health Organization (WHO) estimates that, worldwide, $\mathrm{PM}_{2.5}$ "cause [s] about $8 \%$ of lung cancer deaths, $5 \%$ of cardiopulmonary deaths and about $3 \%$ of respiratory infection death" (WHO 2009). In high-income countries, ambient $\mathrm{PM}_{2.5}$ is the most significant environmental health risk (WHO 2009).

Climate change refers to the change in the state of the climate, both due to natural variability and as a result of human activity (IPCC 2007a). The main indicators of climate change are (1) the concentrations of greenhouse gases (GHG) and aerosols, (2) land cover and (3) radiation (IPCC 2007a). As a result of climate change, the global temperature is expected to increase $1.8-4.0{ }^{\circ} \mathrm{C}$ between 
1980-1999 and 2090-2099, depending on emission scenarios (IPCC 2007b). Climate change is one of the main environmental challenges for humankind in the twenty-first century.

$\mathrm{PM}_{2.5}$ air pollution and climate change are linked on several levels. Particulate matter (as an aerosol) cools the climate (IPCC 2007a). Additionally, the same source emits both $\mathrm{GHG}$ and $\mathrm{PM}_{2.5}$. This means that the mitigation of either $\mathrm{PM}_{2.5}$ or GHG emissions will likely also affect the other (e.g. ApSimon et al. 2009). The integrated assessment models in place, such as GAINS (Greenhouse Gas and Air Pollution Interactions and Synergies, http://gains.iiasa.ac.at/gains/), assess cost-effective mitigation strategies jointly for $\mathrm{PM}_{2.5}$ and GHG emissions.

Climate change affects $\mathrm{PM}_{2.5}$ air pollution concentrations through changes in meteorology. The formation of secondary $\mathrm{PM}_{2.5}$ and dispersion of $\mathrm{PM}_{2.5}$ depends on meteorological parameters, and a change in these parameters will also change the formation and dispersion of PM. A number of studies have examined this issue (e.g. Racherla and Adams 2006; Tagaris et al. 2007, 2009). The review published by Ebi and McGregor (2008) concluded that climate change would increase ozone concentrations if the precursor gas emissions did not change in future decades. Regarding $\mathrm{PM}_{2.5}$, they considered evidence less robust due to lack of published studies. Another review by Jacob and Winner (2009) concluded that different published studies estimate changes of $\pm 1 \mu \mathrm{g} / \mathrm{m}^{3}$ in annual mean $\mathrm{PM}_{2.5}$ concentrations due to climate change in the United States (US) and Europe, with little consensus between studies.

In this study, we examined on how climate change would affect exposure to and adverse health effects caused by $\mathrm{PM}_{2.5}$ air pollution in Poland. We calculated $\mathrm{PM}_{2.5}$ concentration over Poland for three decades: the 1990s, 2040s and 2090s. To account for the impact of climate change, the same population, anthropogenic air pollution emission and background health data were used for all the decades. The exposure for $\mathrm{PM}_{2.5}$ across Poland and in different Polish provinces was predicted for each year.

\section{Materials and methods}

\section{Climate simulations}

For climate simulations, a three-dimensional hydrostatic regional climate model, RegCM3, was employed. The RegCM model was originally developed by Dickinson et al. (1989) and Giorgi and Bates (1989) and is used in a wide range of applications (Giorgi and Mearns 1999; Giorgi et al. 2006), including climate change simulations (Giorgi et al. 1992; Hirakuchi and Giorgi 1995; Diffenbaugh et al. 2005; Gao et al. 2006; Meleux et al. 2007).
The dynamical core of the RegCM3 is based on the hydrostatic version of the NCAR-PSU Mesoscale Model version 5 (MM5) (Grell et al. 1994). In this study, the Grell convective scheme (Grell 1993) with the Fritsch and Chappell (1980) closure assumption was adopted. The RegCM3-beta version (Torma et al. 2011), designed for high-resolution simulations $(10 \mathrm{~km} \times 10 \mathrm{~km})$, was implemented for the modelling domain, centred around Poland $\left(52.00^{\circ} \mathrm{N}, 19.30^{\circ} \mathrm{E}\right)$ on a grid with $120 \times 109$ points and a resolution of $10 \mathrm{~km}$ (Reizer and Juda-Rezler 2010). The map projection choice was Lambert Conformal Conic while the domain's vertical profile contained 18 layers of varying thickness, extending up to $50 \mathrm{hPa}$ (study area is presented in Fig. 1).

To assess meteorological boundary conditions in relation to the regional climate model, we used a double nesting approach, based on the EU-FP6 project ENSEMBLES (http://ensembles-eu.metoffice.com/) simulations. The ECHAM5 global climate model (Roeckner et al. 2003), forced under the SRES A1B IPCC greenhouse gas emission scenario (Nakicenovic et al. 2000) with a 300-km resolution, drove a Europe-wide version of RegCM3 with a $25-\mathrm{km}$ resolution, which in turn drove the RegCM3 $10 \mathrm{~km}$ version applied in this study. The ECHAM5-RegCM3 European simulations were performed at Abdus Salam International Centre for Theoretical Physics (ICTP). The meteorological output fields of RegCM3 were used to drive offline the chemical transport model (CTM) CAMx.

The results of climate simulation are given in Reizer and Juda-Rezler (2010) and Huszar et al. (2011). They calculated warming during the summer ( $2 \mathrm{~m}$ temperature, $\mathrm{T})$, which ranged from 0.4 to $1{ }^{\circ} \mathrm{C}$ in the $2040 \mathrm{~s}$, and from 2 to $3{ }^{\circ} \mathrm{C}$ in the 2090s, in comparison with the 1990s. The summer shortwave radiation levels showed slight decrease $\left(2-10 \mathrm{~W} / \mathrm{m}^{2}\right)$ in the $2040 \mathrm{~s}$ and a slight increase in the same kind in the 2090s. Possible changes in horizontal and vertical mixing were accounted for by the ventilation coefficient, which is defined as the product of horizontal wind speed at the surface and planetary boundary layer height (PBLH), according to Rao et al. (2003). In the 2040s, the ventilation coefficient increased during winter in the southern area of Poland (the area of highest industrial emission) by up to $400 \mathrm{~m}^{2} / \mathrm{s}$ while in autumn, there was no change in the ventilation coefficient for this region and a moderate decrease (up to $200 \mathrm{~m}^{2} / \mathrm{s}$ ) in the rest of the country. In the $2090 \mathrm{~s}$, a decrease in up to $400 \mathrm{~m}^{2} / \mathrm{s}$ was observed for both seasons (Huszar et al. 2011).

\section{Emissions}

In order to study the impact of climate on air quality alone, the anthropogenic primary PM from the year 2000 and its precursors $\left[\mathrm{CO}, \mathrm{NO}_{x}, \mathrm{SO}_{2}, \mathrm{NH}_{3}\right.$, non-methane volatile 
Fig. 1 The study area, location of the provinces and population density for Poland

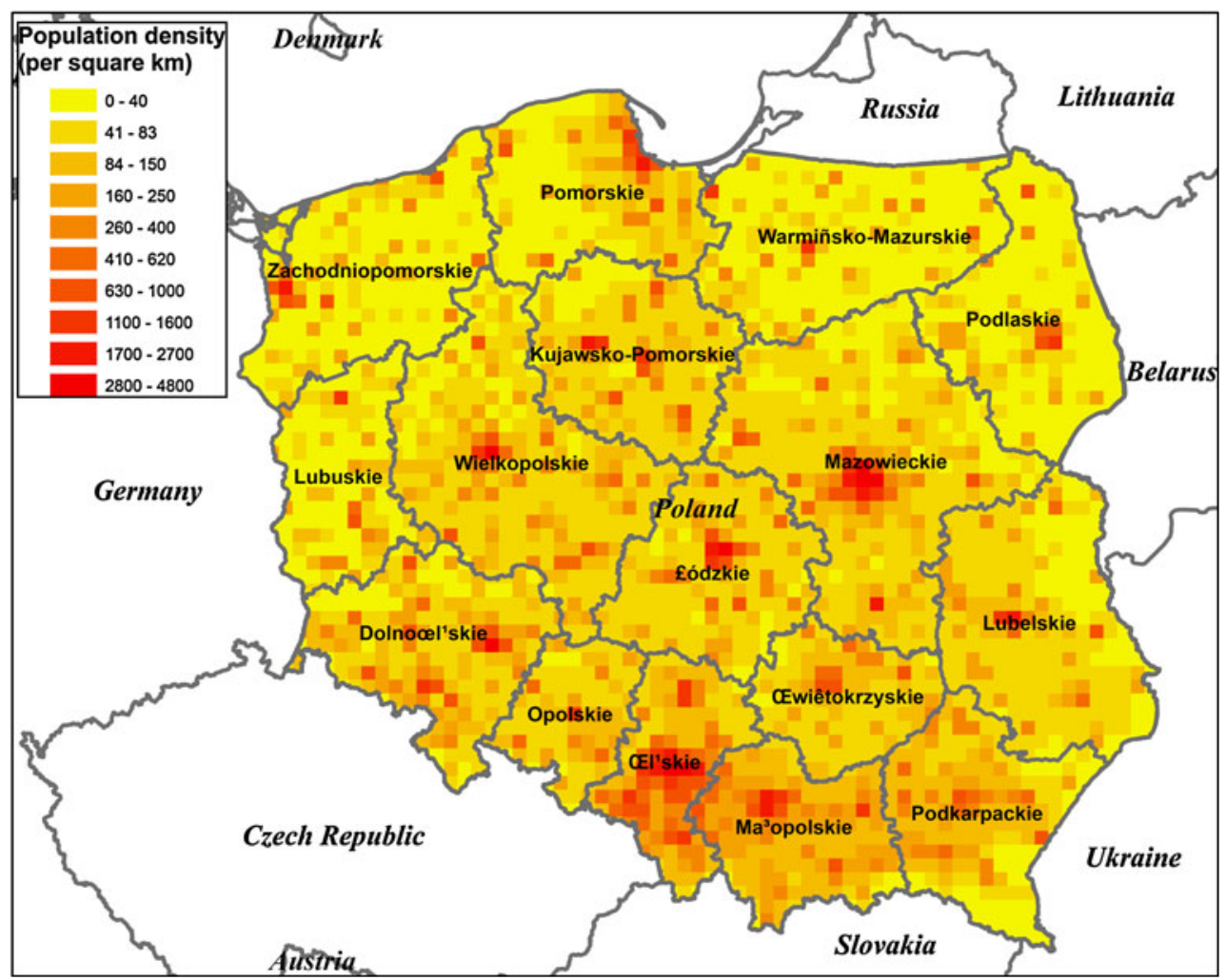

organic compounds (NMVOC) emissions] were used in all simulations. Anthropogenic emissions for Poland were calculated with the emission model EMIL (EMIssion modeL) (Trapp et al. 2010). EMIL follows a modular setup of the SMOKE emission model, which is a part of USEPA Models-3 Community Modelling and Analysis System (CMAS) (Byun and Schere 2006).

Area, mobile and point sources are calculated by different modules and merged into a single output file. For area (municipal, agricultural), mobile and small industrial sources (plants with a thermal input of less than or equal to 50 MWth), the model generates gridded 2D emissions. This is based on detailed emission source inventory that was composed for the reference year of 2000. It used a $1 \mathrm{~km} \times 1 \mathrm{~km}$ resolution, meteorological data and terrain characteristics as well as data on population density, sectorspecific activity, fuel demands and characteristics, and sector-dependent emission factors for Polish sources. For large combustion plants (LCPs) with a thermal input greater than 50 MWth, a 3D emission database was created. It contains data for 220 stacks and consists of the following stack data: name of the LCP, stack number, geographical coordinates, installed technological units, stack height and diameter, temperature of exhaust gases, velocity of exhaust gases and total emission amount. The vertical distribution is calculated in CAMx via Plume in Grid (PiG) algorithms using stack and meteorological data.
This leads to a more realistic spatial and temporal disaggregation of emissions from LCPs.

For other countries belonging to the model domain, the anthropogenic emission database is based on the European Monitoring and Evaluation Program (EMEP) emission inventory (Vestreng et al. 2007). It is available in gridded form on a $50 \mathrm{~km} \times 50 \mathrm{~km}$ EMEP grid system that is based on a polar-stereographic projection. The inventory contains the total annual emission of PM precursors and primary $\mathrm{PM}$, reported as $\mathrm{PM}_{2.5}$, and coarse particles $(2.5-10 \mu \mathrm{m})$. The emissions are distributed over 11 SNAP97 source sectors (Selected Nomenclature for sources of Air Pollution). SNAP97 is a standard defined by the CORINAIR guidebooks, which ensure that emissions reported by different nations are comparable (EEA 2007). These annual total emissions were further disaggregated by time and space. The temporal distribution was determined via sectoral emission profiles from the inventory by Winiwarter and Zueger (1996). For every sector, different distributions accounting for the month, the day of the week and the hour of the day were applied. For the neighbouring countries of Austria, Czech Republic, Hungary and Slovakia the EMEP data were scaled down to a spatial resolution of $5 \mathrm{~km} \times 5 \mathrm{~km}$. An emission inventory by Winiwarter and Zueger (1996) for these countries was used as the basis for the spatial disaggregation of emission within the $50 \mathrm{~km} \times 50 \mathrm{~km}$ EMEP grid cells. The resulting emission 
data were converted into the Lambertian projection. There was no vertical distribution of emission; the whole emission flux was assumed to be released into the surface layer as the area source. Finally, the chemical speciation for $\mathrm{NO}_{x}$, NMVOC and $\mathrm{PM}_{2.5}$ was done, for compatibility with the CBM-IV mechanism of Comprehensive Air quality Model with extensions (CAMx) (see Krüger et al. 2008).

Biogenic emissions were calculated as functions of meteorological parameters and land use. Thus, the biogenic emissions varied with changes in climate. Although changes in land use may be expected in the future, we did not include such changes in our study and kept the land-use data constant. The data from the terrain pre-processor of the regional mesoscale model MM5 (http://www.mmm.ucar.edu/mm5/) were used. They distinguish 25 land-use categories and are based on global data from the United States Geological Survey (USGS). Biogenic emissions of isoprene and monoterpenes were calculated as functions of $2 \mathrm{~m}$ temperature, while global radiation and land-use categories were calculated with the procedure proposed by Guenther et al. (1993). The procedure used for biogenic emission calculations is reported in Katragkou et al. (2010).

\section{Air quality modelling}

The air quality model simulations were carried out with version 4.4 of the CAMx (http://www.camx.com). CAMx is the state-of-the-art three-dimensional chemical transport model that has undergone continuous refinement by the science community over the past decade. It is one of the leading CTMs used for policy and research applications related to ozone and aerosols (Morris et al. 2005; Tesche et al. 2006). CAMx has been applied widely for a variety of purposes (e.g. Morris et al. 2005; Tesche et al. 2006; Andreani-Aksoyoglu et al. 2008; Lonati et al. 2010; Fountoukis et al. 2011). The model simulates the following major chemical and physical processes that are thought to be important for understanding atmospheric trace gas transformations and distributions: (1) emission injections, (2) horizontal and vertical advection, (3) horizontal and vertical diffusion, (4) dry and wet depositions, (5) gasphase and aqueous-phase chemical reactions and (6) aerosol dynamics, thermodynamics and chemistry. CAMx uses a mass conservative and consistent transport numerics in parallel processing. It allows for integrated assessments of gaseous and particulate air pollution over many scales ranging from suburban to continental. The chemistry mechanism invoked is Carbon Bond v. 4 (CB-IV) (Gery et al. 1989), including 117 reactions -11 of which are photolytic - and up to 67 species (37 state gases, up to 18 state particulates and 12 radicals). For aerosol processes, the ISORROPIA thermodynamic equilibrium model (Nenes et al. 1998) is used.
In this study, CAMx was off-line coupled with RegCM3beta using an interface, which reads the basic meteorological parameters from RegCM3 and converts them into a format accepted by CAMx. These parameters include fractional land-use distribution, including 11 land-use categories, threedimensional gridded fields of height/pressure, horizontal wind components, temperature, water vapour concentrations, cloud parameters, vertical diffusivity and two-dimensional surface temperature (ENVIRON 2006). The same horizontal modelling grids with Lambert Conformal Conic map projection were used for RegCM3 and CAMx models in order to avoid interpolations between grids. Vertically, $18 \sigma$-levels were used in RegCM3 while CAMx was run over the lowermost 12 levels of varying thickness. Layer 1 was 36 m deep and the uppermost layer was $1.2 \mathrm{~km}$ thick extending to about $6.5 \mathrm{~km}$. The lateral chemical boundary conditions were provided by the $50 \mathrm{~km} \times 50 \mathrm{~km}$ resolution CAMx simulations performed at University of Natural Resources and Life Sciences in Vienna (Krüger et al. 2008) under the EU-FP6 project CECILIA (http://www.cecilia-eu.org/). Top boundary conditions for all gaseous species were kept constant, with no seasonal variation and annual variability; ozone was set to $40 \mathrm{ppb}, \mathrm{NO}_{2}$ to $1 \mathrm{ppb}$ and $\mathrm{CO}$ to $200 \mathrm{ppb}$.

The results of RegCM3-beta/CAMx simulations were evaluated for the calendar year 2000 using surface observations from 17 monitoring sites from the EMEP (http://www.emep.int) and AirBase (http://acm.eionet. europa.eu/databases/airbase) databases. For winter, annual and daily mean $\mathrm{PM}_{10}$ concentrations and fractional bias (FB) model results amounted to $-2.7,-39.8$ and $-26.0 \%$, fractional error (FE) amounted to 38.1, 41.9 and $62.3 \%$ and index of agreement (IA) amounted to $0.81,0.61$ and 0.57 , respectively (Juda-Rezler et al. 2012). These results show that our modelling system fulfils the skill criteria of $\mathrm{FB} \leq$ $\pm 60 \%$ and $\mathrm{FE} \leq+75 \%$ given by Boylan and Russell (2006) as well as the benchmark for IA $>0.6$ proposed by Gilliam et al. (2006), thus justifying the use of proposed modelling system for future time projections.

Population data and exposure calculations

The exposure of the population to $\mathrm{PM}_{2.5}$ air pollution was calculated by combining population location data with concentration data. Population data were based on the Central Statistical Office of Poland population density estimates from the year 2004. Population densities across Poland are illustrated in Fig. 1 and presented in Table 1. The same 10-km spatial resolution was used in both $\mathrm{PM}_{2.5}$ concentration and population data.

Two different exposure estimates were calculated:

- Average concentration;

- Population-weighted concentration. 
Population-weighted concentration took into account the correlation between $\mathrm{PM}_{2.5}$ concentrations and the location of population and was calculated with the following equation:

$E=\Sigma_{i}\left(C_{i} \times \operatorname{Pop}_{i}\right) / \Sigma_{i}\left(\operatorname{Pop}_{i}\right)$

In this equation, $E$ is exposure (Population-weighted concentration of $\mathrm{PM}_{2.5}$ ) (unit: $\mu \mathrm{g} / \mathrm{m}^{3}$ ) in the given area, $C$ is $\mathrm{PM}_{2.5}$ concentration (unit: $\mu \mathrm{g} / \mathrm{m}^{3}$ ) and Pop is the number of people in grid cell $i$.

All the exposure calculations assume that outdoor concentration of $\mathrm{PM}_{2.5}$ at the home addresses represents the population exposure. A similar assumption has been used in a number of previous studies assessing the scope of adverse health effects caused by $\mathrm{PM}_{2.5}$ (e.g. Greco et al. 2007; Tainio et al. 2010). Exposure estimates were calculated for the population of Poland and for each of its provinces. For the latter, province boundaries from the year 1999 were used (Fig. 1). For the purpose of this study, the population of each $10 \times 10 \mathrm{~km}$ grid belonged to the province in which the central point of the grid was located. The spatial calculations were done with ESRI ArcMap version 9.3. Calculated exposure data were combined with $\mathrm{R}$ version 2.9.2. The locations of provinces are illustrated in Fig. 1 and the population estimates for different provinces in Table 1.
Premature mortality due to $\mathrm{PM}_{2.5}$

The magnitude of the adverse health effects caused by air pollution in Poland was illustrated by calculating premature mortality due to $\mathrm{PM}_{2.5}$. Premature mortality was chosen because it has been widely used in previous impact calculations (e.g. Ebi and McGregor 2008; Tagaris et al. 2009; Tainio et al. 2010). The premature mortality rate was estimated by year and by Polish province. The premature mortality rate was calculated with following equation:

$M=\mathrm{Mb} \times E \times(\mathrm{ER} / 100)$

In the equation, $M$ is premature mortality due to $\mathrm{PM}_{2.5}$ air pollution, $\mathrm{Mb}$ is background non-accidental mortality, $E$ is exposure level and ER is exposure-response function (\% change in the background mortality due to $1 \mu \mathrm{g} / \mathrm{m}^{3} \mathrm{PM}_{2.5}$ exposure).

For the value of ER, we used the estimates from the European expert judgment study (Cooke et al. 2007; Tuomisto et al. 2008). In that study, six European air pollution experts estimated the exposure-response function for the $\mathrm{PM}_{2.5}$ air pollution. The expert estimates were combined with two different methods: equal-weight (EDM) decision maker and performance-based (PDM) decision maker. The main difference between these two methods was that in EDM each expert's answer was combined, giving equal weight to

Table 1 Population and background mortality data for different provinces

\begin{tabular}{|c|c|c|c|c|}
\hline Acronym & $\begin{array}{l}\text { Province } \\
\text { (Polish name) }\end{array}$ & $\begin{array}{l}\text { Province } \\
\text { (English name) }\end{array}$ & Population & $\begin{array}{l}\text { Background } \\
\text { non-accidental mortality }\end{array}$ \\
\hline POL & Polska & Poland & $37,055,702$ & 338,950 \\
\hline DLS & Dolnośląskie & Lower Silesian & $2,727,991$ & 26,019 \\
\hline KPM & Kujawsko-Pomorskie & Kuyavian-Pomeranian & $2,103,549$ & 18,388 \\
\hline LBL & Lubelskie & Lublin & $2,208,251$ & 21,454 \\
\hline LBU & Lubuskie & Lubusz & 973,692 & 8,170 \\
\hline LDZ & Łódzkie & Łódź & $2,567,235$ & 29,620 \\
\hline MLP & Małopolskie & Lesser Poland & $3,448,207$ & 26,563 \\
\hline MAZ & Mazowieckie & Masovian & $5,337,043$ & 47,687 \\
\hline OPL & Opolskie & Opole & 964,950 & 8,751 \\
\hline PKR & Podkarpackie & Subcarpathian & $2,161,395$ & 16,843 \\
\hline PDL & Podlaskie & Podlaskie & $1,265,272$ & 10,836 \\
\hline POM & Pomorskie & Pomeranian & $1,415,512$ & 16,750 \\
\hline SLK & Śląskie & Silesian & $4,365,674$ & 41,996 \\
\hline SWK & Świętokrzyskie & Świętokrzyskie & $1,165,895$ & 12,459 \\
\hline WMZ & Warmińsko-Mazurskie & Warmian-Masurian & $1,419,529$ & 10,688 \\
\hline WKP & Wielkopolskie & Greater Poland & $3,358,632$ & 29,427 \\
\hline ZPM & Zachodniopomorskie & West Pomeranian & $1,506,820$ & 13,299 \\
\hline
\end{tabular}

The population data are based on year 2004 population counts and background mortality to year 2000 data. For the location of provinces, see Fig. 1 
each response, while in PDM the weights were based on socalled calibration questions that aimed to measure the performance of the experts. The estimated mean percentage change in mortality due to $1 \mu \mathrm{g} / \mathrm{m}^{3}$ exposure change in $\mathrm{PM}_{2.5}$ in Europe was 0.62 and $0.95 \%$ for EDM and PDM, respectively (Tuomisto et al. 2008). In this study, the EDM estimate was used. The exposure-response function was assumed to be linear between exposure levels and the zeroexposure. Thus, we did not assume any threshold value for the mortality effect (WHO 2003).

The background non-accidental mortality $(\mathrm{Mb})$ data were calculated for different provinces for the year 2000 (Table 1). Data were prepared by the National Institute of Public HealthNational Institute of Hygiene (NIZP-PZH). The exposure and premature mortality calculations were done with the MonteCarlo simulation program Analytica (version 4.4.).

\section{Results}

The predicted $\mathrm{PM}_{2.5}$ concentrations across Poland in 2000 are illustrated in Fig. 2, and the change in $\mathrm{PM}_{2.5}$ concentrations in Poland over several decades is presented in Fig. 3. The population-weighted concentration of $\mathrm{PM}_{2.5}$ for the 1990s, 2040s and 2090s were 18.3, 17.2 and $17.1 \mu \mathrm{g} /$ $\mathrm{m}^{3}$, respectively (Table 2). The difference in concentrations between the first decade (1990s) and two other decades is statistically significant ( $T$ test, $p$ value less than $0.05)$. On the average, the population-weighted concentration of $\mathrm{PM}_{2.5}$ was 6 and $7 \%$ lower in the 2040s and 2090s in comparison with the 1990s (Table 2).

The average change in $\mathrm{PM}_{2.5}$ concentrations in different provinces is presented in Table 2 . The average $\mathrm{PM}_{2.5}$ concentrations were estimated to change from 2 to $-13 \%$ between 1990s and 2040s in different provinces. Only two provinces showed an increase in $\mathrm{PM}_{2.5}$ concentration between the 1990s and the 2040s. Examining different regions of Poland separately revealed that the reduction in $\mathrm{PM}_{2.5}$ concentration is highest in the eastern part of the country and lowest in the western part. In the 2090s, $\mathrm{PM}_{2.5}$ concentrations were lower than the 1990s concentrations in all the provinces.

The $\mathrm{PM}_{2.5}$ air pollution was estimated to cause 39,800 premature deaths in Poland in 2000 (Fig. 4). If all other parameters except climate were to stay constant, the premature deaths would be 35,800 and 34,900 per year in 2050 and 2100, respectively. Thus, lower exposure would result in a significant reduction in adverse health effects.

\section{Discussion}

In this study, we have estimated the change in exposure to $\mathrm{PM}_{2.5}$ in Poland and the resulting premature mortality rates between current climate and projected future climate. We discovered that exposure to $\mathrm{PM}_{2.5}$ and the associated adverse health effects could decrease in the future due to projected changes in climate. On the average, $\mathrm{PM}_{2.5}$ concentrations were $6 \%$ lower in the 2040s than in the 1990s. Expanding our analysis for the years 2091-2100 did not show significant change in PM concentrations. Examining the impact of climate change in different parts of Poland showed that the reduction in $\mathrm{PM}_{2.5}$ concentration is highest in the eastern part of the country and lowest in the western part. The decrease in $\mathrm{PM}_{2.5}$ concentration is assumed to be a result of the increase in winter precipitation (Juda-Rezler et al. 2012). In two provinces, $\mathrm{PM}_{2.5}$ concentrations were expected to increase between the 1990s and the 2040s. $\mathrm{PM}_{2.5}$ caused an estimated 39,800 premature deaths annually in Poland in the year 2000.

A reduction in $6 \%$ in $\mathrm{PM}_{2.5}$ concentrations between 1990s and 2040s may have a significant effect on calculating cost-effectiveness. In a cost -effectiveness study conducted in the US (Liao et al. 2010), the research team concluded that 4.1 billion dollars are required to offset the increase in $\mathrm{PM}_{2.5}$ and ozone concentration between years 2000-2002 and 2049-2051. Although their study included both ozone and $\mathrm{PM}_{2.5}$ and they estimated that the concentrations of both pollutants would increase in future, the study gives an indication of the cost of combating air pollution problems. Based on our study, the situation is different in Poland since climate change itself will presumably reduce $\mathrm{PM}_{2.5}$ concentrations. This means that fewer preventative actions may be required to meet guidelines such as the European Union Air Quality Directive (2008/50/EC).

Our study was done with constant anthropogenic $\mathrm{PM}_{2.5}$ and precursor gas emission, population and background health effect parameters. This does not present a realistic scenario because in the future all of these parameters will change. This modelling approach was chosen in order to separate the impact of climate change from other major factors. Therefore, these results should be viewed as more indicative of future $\mathrm{PM}_{2.5}$ concentrations rather than as a realistic assessment of the situation in the 2040s or 2090s.

We did not specifically investigate the question of why the $\mathrm{PM}_{2.5}$ concentrations are lower in future climate because such analyses have been performed in Juda-Rezler et al. (2012). In that study, the decrease was mainly associated with the increase in winter precipitation in future decades and small changes in mixing height were not found to significantly affect $\mathrm{PM}_{10}$. Additionally, in the review by Jacob and Winner (2009), precipitation, which directly affects the main removal mechanism of PM, and wet deposition were assumed to play important role in decreasing the $\mathrm{PM}_{2.5}$ concentrations. An increase in mixing height was also recognised to affect $\mathrm{PM}_{2.5}$ concentration; 

Poland in 2000
Fig. $2 \mathrm{PM}_{2.5}$ concentrations in

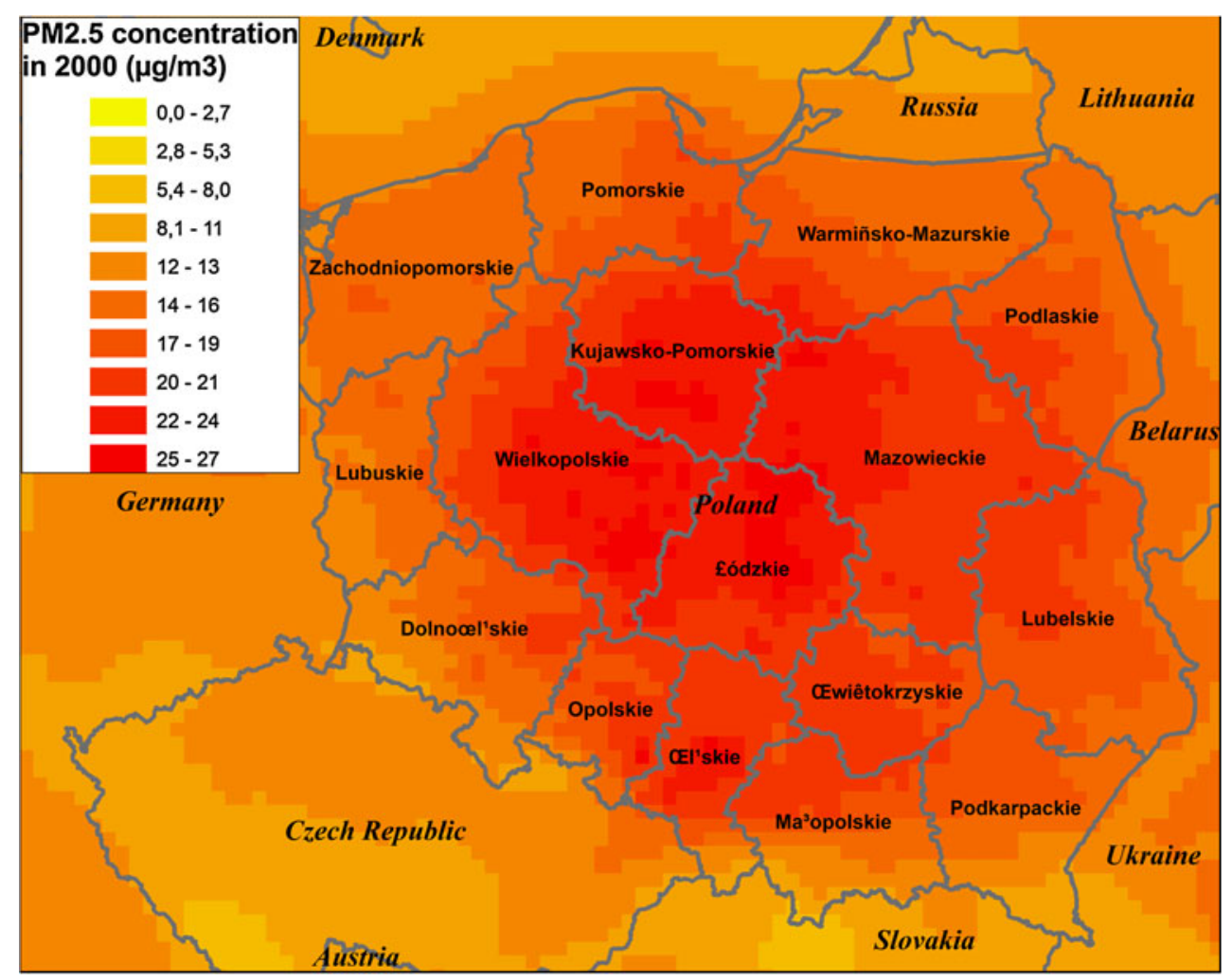

Fig. 3 Average $\mathrm{PM}_{2.5}$ concentrations in Poland in different decades

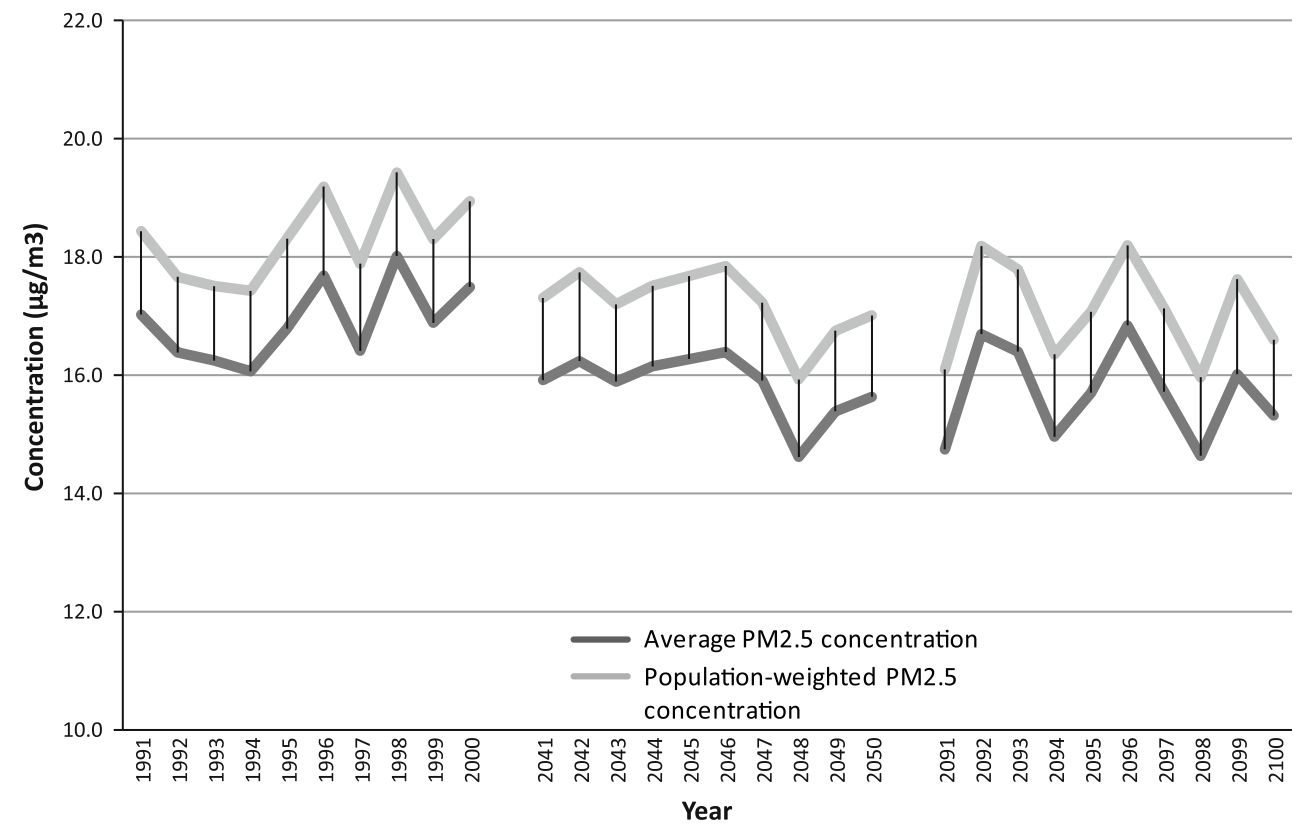

however, the direction of change was specific to region and PM constituent (Jacob and Winner 2009). In our study, precipitation change was identified as the major reason for lower $\mathrm{PM}_{2.5}$ concentrations in 2040s.

Climate change did not, however, have any further significant impact on $\mathrm{PM}_{2.5}$, despite the further increase in precipitation in 2090s. The cause of this phenomenon is not easy to explain. As was concluded by Juda-Rezler et al.
(2012), the main difficulty of interpreting projected PM levels has to do with the fact that the effects of climate change on PM depend on PM composition and the interrelated, complex processes that PM components undergo in the atmosphere. As we simulated only $\mathrm{PM}_{2.5}$ mass concentration, the lack of knowledge about the particulate matter species limits the interpretation. One should also consider that all presented concentrations are averaged, 
Table 2 Exposure for $\mathrm{PM}_{2.5}$ in different provinces, in three different decades

\begin{tabular}{|c|c|c|c|c|c|}
\hline \multirow[t]{2}{*}{ Province } & \multicolumn{3}{|c|}{ Population-weighted $\mathrm{PM}_{2.5}$ concentration } & \multicolumn{2}{|c|}{ Difference $(\%)$ in comparison with $1991-2000$} \\
\hline & $1991-2000$ & $2041-2050$ & $2091-2100$ & $2041-2050$ & $2091-2100$ \\
\hline Poland & 18.3 & 17.2 & 17.1 & -6 & -7 \\
\hline Lower Silesian & 15.5 & 15.1 & 14.8 & -2 & -4 \\
\hline Kuyavian-Pomeranian & 21.3 & 19.6 & 19.7 & -8 & -7 \\
\hline Lublin & 17.6 & 16.1 & 15.9 & -8 & -10 \\
\hline Lubusz & 14.1 & 14.4 & 14.0 & 2 & -1 \\
\hline Łódź & 22.1 & 20.6 & 20.5 & -7 & -7 \\
\hline Lesser Poland & 17.6 & 16.7 & 16.6 & -5 & -6 \\
\hline Masovian & 20.0 & 18.3 & 18.4 & -8 & -8 \\
\hline Opole & 17.9 & 17.2 & 16.9 & -4 & -6 \\
\hline Subcarpathian & 16.1 & 15.2 & 14.9 & -6 & -7 \\
\hline Podlaskie & 16.0 & 14.0 & 13.9 & -13 & -13 \\
\hline Pomeranian & 15.6 & 14.5 & 14.6 & -7 & -7 \\
\hline Silesian & 20.6 & 19.9 & 19.7 & -3 & -4 \\
\hline Świętokrzyskie & 18.8 & 17.5 & 17.3 & -7 & -8 \\
\hline Warmian-Masurian & 15.7 & 14.1 & 14.2 & -10 & -9 \\
\hline Greater Poland & 20.8 & 19.7 & 19.5 & -5 & -6 \\
\hline West Pomeranian & 14.1 & 14.1 & 13.7 & 0 & -3 \\
\hline
\end{tabular}

Fig. 4 Premature death estimates for year 2000 for different provinces. For the location of provinces, see Fig. 1

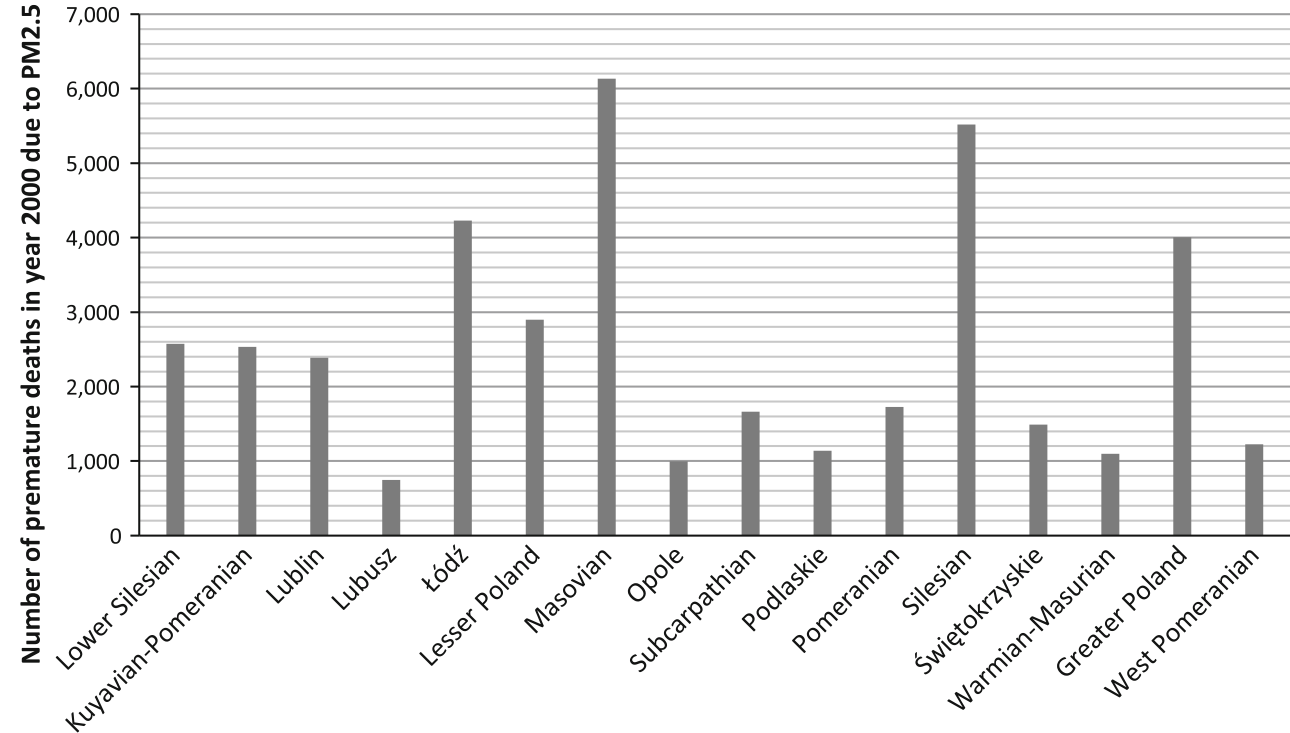

Province in Poland which substantially complicates the discussion. Although it seems that in the 2090s a precipitation-driven decrease in $\mathrm{PM}_{2.5}$ was suppressed by other processes, these processes were probably driven by the increased $\mathrm{T}$ : (1) faster $\mathrm{SO}_{2}$ oxidation to sulphate aerosol; (2) higher water vapour content related to the rise of temperatures, which also results in faster $\mathrm{SO}_{2}$ oxidation; and (3) higher biogenic emission of hydrocarbons being precursors of SOA (Secondary Organic Aerosol). A decrease in the ventilation coefficient during winter and autumn (when the highest emissions of PM occurs) is another likely cause suppressing the aforementioned precipitation-driven decrease in $\mathrm{PM}_{2.5}$.

Comparison to previous studies

Several studies have considered the impact of climate change on $\mathrm{PM}_{2.5}$ concentrations in different geographical areas and with different model assumptions. For example, Racherla and Adams (2006) estimated global changes in 
ozone and particulate matter concentrations between 1990s and 2050s. They concluded that annual average surface concentrations of particulate matter were increasing and decreasing in different parts of the world so that there was in practise zero change in $\mathrm{PM}_{2.5}$ concentration on a global scale. However, they did estimate a reduction in the lifetime of $\mathrm{PM}_{2.5}$ of 2-18\% (Racherla and Adams 2006). Racherla and Adams (2006) considered the changes in meteorological conditions between 1990s and 2050s as well as changes in natural emissions. Other main parameters were kept constant. For Poland, they estimated that the concentrations of some of the $\mathrm{PM}_{2.5}$ components were increasing and that some were decreasing. They did not specifically investigate the reasons for these changes in Poland but seasonal-scale precipitation decrease in the region was assumed to be the likely reason for higher surface layer concentrations.

Tagaris et al. (2007) estimated $\mathrm{PM}_{2.5}$ concentrations in the US for the year 2050 with two different models. The first model took into account changes in climate and the other model accounted for both climate change and emissions. They found out that in 2050 , the annual average concentration of $\mathrm{PM}_{2.5}$ would be approximately $1 \%$ higher due to changes in the climate. When both meteorology and emissions reductions were taken into account, the $\mathrm{PM}_{2.5}$ concentrations were $23 \%$ lower in the year 2050. Tagaris et al. (2009) expanded assessment by estimating the adverse health effects caused by $\mathrm{PM}_{2.5}$ and ozone in the US. They found out that 4,000 more premature deaths would occur in 2050 than in 2001 due to increased $\mathrm{PM}_{2.5}$ concentrations. The same air pollution emissions data were used for both 2001 and 2050, so we may conclude that the increased mortality rate is due entirely to changes in climate conditions.

\section{Uncertainties and limitations}

We estimated $\mathrm{PM}_{2.5}$ concentrations across Poland using a spatial resolution of approximately $10 \mathrm{~km}$. The spatial variability of $\mathrm{PM}_{2.5}$ concentrations is high due to local emissions. Using a spatial resolution of several kilometres mainly reveals the changes in background concentrations. However, people also inhale $\mathrm{PM}_{2.5}$ air pollution next to emission sources, especially if the source has low emission height and is emitting particles near the general population (like traffic, for example). This might mean that population exposure for some of the $\mathrm{PM}_{2.5}$ has been underestimated (Taimisto et al. 2011). However, since climate change is assumed to have the greatest effect on widely dispersed pollutants, we assume that this possible underestimation of exposure did not have any significant impact on our conclusions.

We focused on the change in climate and how that would affect $\mathrm{PM}_{2.5}$ concentrations and adverse health effects caused by $\mathrm{PM}_{2.5}$. Most of the previous studies mentioned in this article have estimated the change in both ozone and $\mathrm{PM}_{2.5}$ concentrations (e.g. Racherla and Adams 2006; Tagaris et al. 2007). While the impact of climate change to $\mathrm{PM}_{2.5}$ has been uncertain, most of the studies have estimated that ground level ozone would increase. However, when the health effects were taken into account, the increase in $\mathrm{PM}_{2.5}$ concentration had an observed impact that was 15 times greater than ozone (Tagaris et al. 2009). In Poland, ozone limits were exceeded every year, mainly in unpolluted areas of the central and western parts of the country (IOS 2010). When compared to $\mathrm{PM}_{2.5}$, ozone is not a significant health threat in Poland (Wagner et al. 2010), and therefore, it is unlikely that considering ozone in our calculations would change our conclusions.

Several other studies chose to vary parameters that we kept constant. Tagaris et al. (2007), for example, focused on changes in anthropogenic emissions. As has been discussed earlier, they found that the $\mathrm{PM}_{2.5}$ concentration would decrease by $23 \%$ in the USA from the years 2001 to 2050. Spracklen et al. (2009) estimated the change in wildfire smoke levels in USA, and they assumed that climate change would increase the area burned in the western USA by $54 \%$. These wildfires were then estimated to increase the summertime organic carbon concentrations by $40 \%$ and elemental carbon concentrations by $20 \%$ from 2000 to 2050. Biomass burning in Eastern Europe has been noticed to cause $\mathrm{PM}_{2.5}$ concentration peaks across large areas of Europe (Niemi et al. 2009), and consequently, climate change could increase $\mathrm{PM}_{2.5}$ episodes also in Poland.

\section{Conclusions}

Estimates indicate that $\mathrm{PM}_{2.5}$ air pollution caused tens of thousands of premature deaths in Poland in year 2000. Climate change estimates in Poland suggest a decrease in exposure to $\mathrm{PM}_{2.5}$ of approximately $6 \%$ between 1990 and 2040 thus also lowering the rate of premature deaths caused by $\mathrm{PM}_{2.5}$ by $6 \%$. Expansion of our analysis to the 2090s did not result in a similar reduction, indicating that the climate impact on $\mathrm{PM}_{2.5}$ dispersion will occur in the coming few decades. These results will become extremely important in the process of planning cost-effective preventative actions in Poland.

Acknowledgments This work was partly supported by the Central and Eastern Europe Climate Change Impact and Vulnerability Assessment Project (CECILIA), financed by EU 6.FP, Contract GOCE 037005 to Warsaw University of Technology, Warsaw, Poland. The air quality simulations were carried out at the Academic Computer Center in Gdańsk, Poland on cluster supercomputer GALERA. We would like to thank Erica Coppola from ICTP in 
Trieste, Italy and Bernd C. Krüger from the University of Natural Resources and Life Sciences in Vienna, Austria for providing climatic and chemical boundary conditions, respectively, and for inspiring discussions. Special thanks to CECILIA project Leader, Tomas Halenka from Charles University, Prague, Czech Republic. We would also like to thank Ms. Anna Wójtowicz for checking the English language.

Open Access This article is distributed under the terms of the Creative Commons Attribution License which permits any use, distribution, and reproduction in any medium, provided the original author(s) and the source are credited.

\section{References}

Andreani-Aksoyoglu S, Keller J, Prévôt ASH, Baltensperger U, Flemming J (2008) Secondary aerosols in Switzerland and northern Italy: Modeling and sensitivity studies for summer 2003. J Geophys Res 113. doi:10.1029/2007JD009053

Apsimon H, Amann M, Astrom S, Oxley T (2009) Synergies in addressing air quality and climate change. Clim Policy 9(6):669-680

Boylan JW, Russell AG (2006) PM and light extinction model performance metrics, goals, and criteria for three-dimensional air quality models. Atmos Environ 40:4946-4959

Byun D, Schere KL (2006) Review of the governing equations, computational algorithms, and 21 other components of the Models-3 Community Multiscale Air Quality (CMAQ) modeling 22 system. Appl Mech Rev 59:51-77

Cohen AJ, Anderson HR, Ostro B, Pandey KD, Krzyzanowski M, Kunzli N, Gutschmidt K, Pope A, Romieu I, Samet JM, Smith K (2005) The global burden of disease due to outdoor air pollution. J Toxicol Environ Health A 68:1-7

Cooke RM, Wilson AM, Tuomisto JT, Morales O, Tainio M, Evans JS (2007) A probabilistic characterization of the relationship between fine particulate matter and mortality: elicitation of European experts. Environ Sci Technol 41(18):6598-6605

Dickinson RE, Errico RM, Giorgi F, Bates G (1989) A regional climate model for the western United States. Clim Change 15:383-422

Diffenbaugh NS, Pal JS, Trapp RJ, Giorgi F (2005) Fine scale processes regulate the response of extreme events to global climate change. Proc Natl Acad Sci USA 102(44):15774-15778

Ebi KL, McGregor G (2008) Climate change. Tropospheric ozone and particulate matter, and health impacts. environ health. Perspective 116(11):1449-1455

EEA (European Environment Agency) (2007) EMEP/CORINAIR emission inventory guidebook. Technical report no 16/2007. European Environment Agency, Copenhagen

ENVIRON (2006) CAMx users' guide, version 4.40. ENVIRON International Corporation, Novato, CA

Fountoukis C, Racherla PN, van der Gon HACD, Polymeneas P, Charalampidis PE, Pilinis C, Wiedensohler A, Dall'Osto M, O'Dowd C, Pandis SN (2011) Evaluation of a three-dimensional chemical transport model (PMCAMx) in the European domain during the EUCAARI May 2008 campaign. Atmos Chem Phys 11:10331-10347

Fritsch JM, Chappell CF (1980) Numerical prediction of convectively driven mesoscale pressure systems. Part I: convective parameterization. J Atmos Sci 37:1722-1733

Gao X, Pal JS, Giorgi F (2006) Projected changes in mean and extreme precipitation over the Mediterranean region from high resolution double nested RCM simulations. Geophys Res Lett 33(3). doi:10.1029/2005GL024954
Gery MW, Whitten GZ, Killus JP, Dodge MC (1989) A photochemical kinetics mechanism for urban and regional scale computer modelling. J Geophys Res 94:12925-12956

Gilliam RC, Hogrefe C, Rao ST (2006) New methods for evaluating meteorological models used in air quality applications. Atmos Environ 40:5073-5086

Giorgi F, Bates GT (1989) On the climatological skill of a regional model over complex terrain. Mon Weather Rev 117:2325-2347

Giorgi F, Mearns LO (1999) Introduction to special section: regional climate modelling revisited. J Geophys Res 104:6335-6352

Giorgi F, Marinucci MR, Visconti G (1992) A 2XCO2 climate change scenario over Europe generated using a limited area model nested in a general circulation model, II: climate change scenario. J Geophys Res 97:10028-19911

Giorgi F, Pal JS, Bi X, Sloan L, Elguindi N, Solmon F (2006) Introduction to the TAC special issue: the RegCNET network. Theor Appl Climatol 86(1-4):1-4

Greco SL, Wilson AM, Hanna SR, Levy JI (2007) Factors influencing mobile source particulate matter emissions-to-exposure relationships in the Boston urban area. Environ Sci Technol 41: $7675-7682$

Grell G (1993) Prognostic evaluation of assumptions used by cumulus parameterizations. Mon Weather Rev 121:764-787

Grell GA, Dudhia J, Stauer DR (1994) A description of the fifthgeneration Penn State/NCAR mesoscale model (MM5), Technical report NCAR/TN-398 + STR. National Center for Atmospheric Research, Boulder, CO

Guenther AB, Zimmermann PC, Harley R, Monson RK, Fall R (1993) Isoprene and monoterpene emission rate variability: model evaluations and sensitivity analyses. J Geophys Res 98:12609-12617

Hirakuchi H, Giorgi F (1995) Multi year present day and 2XCO2 simulations of monsoon-dominated climate over Eastern Asia and Japan with a regional climate model nested in a general circulation model. J Geophys Res 100:21105-21126

Huszar P, Juda-Rezler K, Halenka T, Chervenkov H, Syrakov D, Krüger BC, Zanis P, Melas D, Katragkou E, Reizer M, Trapp W, Belda M (2011) Effects of climate change on ozone and particulate matter over Central and Eastern Europe. Clim Res 50:51-68

IOS (Chief Inspectorate for Environmental Protection) (2010) Report on the state of the environment in Poland 2008. Environmental Monitoring Library, Warsaw 2010. http://www.gios.gov.pl/ zalaczniki/artykuly/SOER_PL_2008_angielski.pdf

IPCC (Intergovernmental Panel on Climate Change) (2007) Climate change 2007: synthesis report. In: Core Writing Team, Pachauri, RK, Reisinger A (eds) IPCC, Geneva, Switzerland, p 104

IPCC (Intergovernmental Panel on Climate Change) (2007) Climate change 2007: impacts, adaptation and vulnerability. In: Solomon S, Qin S, Manning M, Chen Z, Marquis M, Averyt KB, Tignor M, Miller HL (eds) Cambridge University Press, Cambridge

Jacob DJ, Winner DA (2009) Effect of climate change on air quality. Atmos Environ 43(1):51-63

Juda-Rezler K, Reizer M, Huszar P, Krüger BC, Zanis P, Syrakov D, Katragkou E, Trapp W, Melas D, Chervenkov H, Tegoulias I, Halenka T (2012) Modelling the effects of climate change on air quality over Central and Eastern Europe: concept, evaluation and projections. Clim Res 53(3):179-203

Katragkou E, Zanis P, Tegoulias I, Melas D, Kioutsioukis I, Krüger BC, Huszar P, Halenka T, Rauscher S (2010) Decadal regional air quality simulations over Europe in present climate: near surface ozone sensitivity to external meteorological forcing. Atmos Chem Phys 10:11805-11821

Krüger BC, Katragkou E, Tegoulias I, Zanis P, Melas D, Coppola E, Rauscher S, Huszar P, Halenka T (2008) Regional photochemical model calculations for Europe concerning ozone levels in a changing climate. Q J Hung Meteorol Serv 112(3-4):285-300 
Liao KJ, Tagaris E, Russell AG, Amar P, He S, Manomaiphiboon K, Woo JH (2010) Cost analysis of impacts of climate change on regional air quality. J Air Waste Manag Assoc 60(2):195-203

Lonati G, Pirovano G, Sghirlanzoni GA, Zanoni A (2010) Speciated fine particulate matter in Northern Italy: a whole year chemical and transport modelling reconstruction. Atmos Res 95:496-514

Meleux F, Solmon F, Giorgi F (2007) Increase in summer European ozone amounts due to climate change. Atmos Environ 41(35):7577-7587

Morris R, Koo B, Yarwood G (2005) Evaluation of multisectional and two-section particulate matter photochemical grid models in the Western United States. J Air Waste Manag Assoc 55:1683-1693

Nakicenovic N, Alcamo J, Davis G, de Vries HJM, Fenhann J, Gaffin S, Gregory K, Grubler A, Jung TY, Kram T, La Rovere L, Michaelis L, Mori S, Morita T, Papper W, Pitcher H, Price L, Riahi K, Roehrl A, Rogner H-H, Sankovski A, Schlesinger M, Shukla P, Smith S, Swart R, van Rooijen S, Victor N, Dadi Z (2000) Special report on emission scenarios. Cambridge University Press, Cambrigde

Nenes A, Pandis SN, Pilinis C (1998) ISORROPIA: a new thermodynamic equilibrium model for multiphase multicomponent inorganic aerosols. Aquat Geochem 4:123-152

Niemi JV, Saarikoski S, Aurela M, Tervahattu H, Hillamo R, Westphal DL, Aarnio P, Koskentalo T, Makkonen U, Vehkamaki H, Kulmala M (2009) Long-range transport episodes of fine particles in southern Finland during 1999-2007. Atmos Environ 43(6): 1255-1264

Racherla PN, Adams PJ (2006) Sensitivity of global tropospheric ozone and fine particulate matter concentrations to climate change. J Geophys Res 1-11, D24103

Rao ST, Ku J-Y, Berman S, Zhang K, Huiting M (2003) Summertime characteristics of the atmospheric boundary layer and relationships to ozone levels over the Eastern United States. Pure Appl Geophys 160:21-55

Reizer M, Juda-Rezler K (2010) The projected influences of climate change on selected meteorological parameters over Poland. In: Konieczyński $\mathrm{J}$ (ed) Air protection in theory and practice. Institute of Environmental Engineering of the Polish Academy of Sciences, Zabrze, pp 271-281 (in Polish)

Roeckner E, Bäuml G, Bonaventura L, Brokopf R, Esch M, Giorgetta M, Hagemann S, Kirchner I, Kornblueh L, Manzini E, Rhodin A, Schlese U, Schulzweida U, Tompkins A (2003) The atmospheric general circulation model ECHAM5. PART 1: model description. Report 349. Max Planck Institute for Meteorology, Hamburg

Spracklen DV, Mickley LJ, Logan JA, Hudman RC, Yevich R, Flannigan MD, Westerling AL (2009) Impacts of climate change from 2000 to 2050 on wildfire activity and carbonaceous aerosol concentrations in the western United States. J Geophys Res $1-17$, D20301

Tagaris E, Manomaiphiboon K, Liao KJ, Leung LR, Woo JH, He S, Amar P, Russell AG (2007) Impacts of global climate change and emissions on regional ozone and fine particulate matter concentrations over the United States. J Geophys Res 1-11, D14312

Tagaris E, Liao KJ, Delucia AJ, Deck L, Amar P, Russell AG (2009) Potential impact of climate change on air pollution-related human health effects. Environ Sci Technol 43(13):4979-4988
Taimisto P, Tainio M, Karvosenoja N, Kupiainen K, Porvari P, Karppinen A, Kangas L, Kukkonen J, Tuomisto JT (2011) Evaluation of intake fractions for different subpopulations due to primary fine particulate matter (PM2.5) emitted from domestic wood combustion and traffic in Finland. Air Qual Atmos Health 4(3-4):199-209

Tainio M, Tuomisto JT, Pekkanen J, Karvosenoja N, Kupiainen K, Porvari P, Sofiev M, Karppinen A, Kangas L, Kukkonen J (2010) Uncertainty in health risks due to anthropogenic primary fine particulate matter from different source types in Finland. Atmos Environ 44(17):2125-2132

Tesche TW, Morris R, Tonnesen G, McNally D, Boylan J, Brewer P (2006) CMAQ/CAMx annual 2002 performance evaluation over the eastern US. Atmos Environ 40:4906-4919

Torma C, Coppola E, Giorgi F, Bartholy J, Pongrácz R (2011) Validation of a high-resolution version of the regional climate model RegCM3 over the Carpathian basin. J Hydrometeorol 12:84-100

Trapp W, Juda-Rezler K, Warchałowski A, Reizer M, Paciorek M, Paciorek MK (2010) Modelling of PM10 and PM2.5 particulate matter air pollution in Poland. In: Pawłowski L, Dudzińska M, Pawłowski A (eds) Environmental engineering III. CRC Press, Boca Raton, pp 97-104

Tuomisto JT, Wilson A, Evans JS, Tainio M (2008) Uncertainty in mortality response to airborne fine particulate matter: combining European air pollution experts. Reliab Eng Syst Saf 93(5): 732-744

Vestreng V, Myhre G, Fagerli H, Reis S, Tarrasón L (2007) Twentyfive years of continuous sulphur dioxide emission reduction in Europe. Atmos Chem Phys 7:3663-3681

Wagner F, Amann M, Bertok I, Cofala J, Heyes C, Klimont Z, Rafaj P, Schöpp W (2010) Baseline emission projections and further cost-effective reductions of air pollution impacts in Europe-A 2010 perspective. NEC scenario analysis report no 7. International Institute for Applied Systems Analysis (IIASA). http://ec.europa.eu/environment/air/pollutants/pdf/nec7.pdf

Watkiss P, Pye S, Holland M (2005) Baseline scenarios for service contract for carrying out cost-benefit analysis of air quality related issues, in particular in the clean air for Europe (CAFE) programme. AEAT/ED51014/Baseline Issue 5. Didcot, UK

WHO (World Health Organization) (2003) Health aspects of air pollution with particulate matter, ozone and nitrogen dioxide. Report on a WHO Working Group, Bonn, Germany, 13-15 Jan 2003

WHO (World Health Organization) (2009) Global health risks: mortality and burden of disease attributable to selected major risks. ISBN:978 924156387 1. http://www.who.int/healthinfo/ global_burden_disease/GlobalHealthRisks_report_full.pdf

Winiwarter W, Zueger J (1996) Pannonisches Ozonprojekt, Teilprojekt Emissionen. Endbericht. Report OEFZS-A-3817, Austrian Research Center, Seibersdorf 